"Woods, pastures, Oct., Sept. Pileus $3 \frac{3}{4}$ diam. stem $2 \frac{5}{8}$ in. long, I $\frac{1}{8}$ in. thick."

And what should this be called? It cannot be called Hygrophorus latitabundus Britz., because that species is as imperfectly described as was $H$. Clarkii B. \& Br., let us therefore call it number three.

We have thus the following three species:-

I. Hygrophorus Clarkii B. \& Br.

2. Hygrophorus Clarkii Massee.

3. Hygrophorus Clarkii W. G. Smith.

Not to mention-

4. Hygrophorus Clarkii Cooke Illustrations, pl. 934, fig. A, which is evidently not Hygrophorus Clarkii at all, but, possibly a variety of Hygrophorus unguinosus.

What is Hygrophorus Clarkii Berk \& Br.? And it appears to us, that, unless Worthington Smith's figures be accepted as evidence, we must conclude that "nobody knows," and hence it had better be ignored, as a species, and sa- "close the book."

NoTE.-Worthington G. Smith's grim satire on Modern Nomenclature as applied to Hymenomycetal Fungi is lately published under the title of "Synopsis of British Basidiomycetes." It is to be regretted that an otherwise useful work should have to be sacrificed to that demon of humour which presided over Gulliver's Travels. Unfortunately there are students who will be accepting all the "emendations" as of serious intent. Names and authorities are getting so mixed that species will soon have to be known, like convicts, by their numbers. M. C. C.

\title{
OMITTED ASCI MEASUREMENTS OF SOME BRITISH DISCOMYCETES.
}

\author{
By Charles Crossland, F.L.S.
}

Many years ago, Mr. Massee strongly recommended me, when examining fungi of any description, to take careful notes and make sketches of all micro-features possible. This most excellent advice has been followed whenever opportunity and time have allowed; thus a pile of information has accumulated, which, eventually, has enabled me to add numerous details to the diagnoses of many incompletely described species. My attention in this direction has been given mostly to the Discomycetes, 
a group of fungi full of fascinating interest, exceeded only, perhaps, by the kindred group-the Pyrenomycetes.

When first I began to make notes and drawings, I established the practice of taking as full a description as lay in my power direct from the specimens themselves, apart altogether from any book information that might have been published respecting them; books were then referred to in the hope of fitting my fungus to some already-described species; if unsuccessful, specimens were submitted to some acknowledged authority. In the determination of species, my principal care has been to make certain, so far as possible, of the identity of the individuals dealt with; this is not always an easy matter to do to your own satisfaction. When there has been room for reasonable doubt, the specimens, drawings and notes, have been laid on one side awaiting further light being thrown upon them. A few are there yet.

The purpose of this paper is to give some of the results of my investigations on the fructifications of British Discomycetes bearing chiefly on the dimensions of the asci, and to supply numerous omissions of asci measurements in the published diagnoses of members in this group. All the figures were taken from living material, and many of them have been checked several times over.

It is only within recent years that measurements of asci have been systematically included in the diagnoses of ascomycetous fungi in this country. In 1897, Mr. Massee gave a valuable series in his "Monograph of the Geoglosseae" (Ann. Bot. xi., pp. 225306). They are also included in "Researches on Coprophilus Fungi " by Massee and Salmon (l.c. xv., pp. 314-357 ; xvi., pp. 57-93); in the descriptions of all New and Critical Discomycetes published from time to time, by the writer and others, in "The Naturalist" for many years back; in the Transactions of the British Mycological Society from the first issue onwards; and in the Journal of Botany, and other British publications. Prof. Saccardo included all that were at his disposal during the compilation of his notable work- "Sylloge Fungorum." Continental authors preceded us in this matter, and the Americans have long considered Discomycete diagnoses incomplete that did not include ascus measurements, and doubtless students universally are now of the same opinion.

Notwithstanding this general decision to include the length and thickness of the ascus in the description of a discomycete, there may be room to question whether these characters are of much real assistance in determining critical or closely allied species. Their comparative features are certainly of much less value than those possessed by the spores for the identification of species; yet, the characters of fungi generally are so few 
that every ascertainable detail of their structure should be taken note of. They are but the hyaline sacs within which the spores are developed. In shape they range from globose, elliptical, or oblong footless bodies, to clavate, cylindric-clavate, and cylindrical structures with short or long pedicels. In the Discomycetes they are mostly pedicellate, but this begins to disappear in the lower members of the Ascobolaceae.

On taking the dimensions of asci, it is found that what appears to be equally mature asci vary both in length and diameter within certain limits in the same pinch of hymenium. Thus it is necessary to give a maximum and minimum length and width, e.g.:-

$$
\begin{aligned}
& \text { Rhizina inflata ................ 480-530 } \times 12-16 \mu . \\
& \text { Gyromitra esculenta ........... 450-480 } \times 14-16 \mu . \\
& \text { Helvella crispa ............... 290-310 } \times 17-19 \mu . \\
& \text { Sclerotinia tuberosa ............. I } 90-200 \times 9-10 \mu .
\end{aligned}
$$

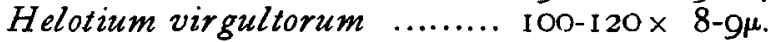

$$
\begin{aligned}
& \text { herbarum ........... } 70-80 \times 6-8 \mu \text {. } \\
& \text { Dasyscypha virginea ............ } 50-60 \times \quad 5-6.5 \mu \text {. } \\
& \text { Mollisia dilutella .............. 40- } 44 \times 6-7 \mu \text {. } \\
& \text { Dasyscypha acuum ............ 22- } 26 \times 4-5 \mu \text {. }
\end{aligned}
$$

and so on; these approximate dimensions are the best we can hope to get. They vary to the greatest extent, both in length and stoutness, in the Ascobolaceae. This we might expect from their luxuriant method of growth. Take for example, Ascobolus immersus-280-360 $\times 80-120 \mu$. : Rabh. Krypt. Flo. says-600 $\times 90-105 ;$ Ascophanus carneus-240-280 $\times 18-28 \mu$. : Rabh. Krypt. Flo. says-100-200 $\times 20-30 \mu$. A case of Lachnea coprinaria may be cited in which the length of the ascus appeared to detract from the width; in one specimen I found them $180-200 \times 24 \mu$; in another $210-300 \times 14-16 \mu$. There may be in some cases a certain amount of tension exercised on the ascus immediately prior to the expulsion of its spores; on one occasion I had just measured an ascus of Bulgaria polymorpha, when it suddenly shot its spores and as suddenly contracted in length from $220 \mu-160 \mu$. Pedicels may also vary in length; in a specimen of Ascobolus Kerverni, the total length of one ascus was $190 \mu$-body $140 \mu$, pedicel $50 \mu$; in another measuring $150 \mu$ the body was $140 \mu$ long and the pedicel only $10 \mu$.

One may ask-when are we to know when an ascus has arrived at its mature length? According to my experience the arrangement of the spores in a continuous, single, double, or irregular series in the upper portion of this organ affords the safest evidence of the maturity of both. This does not, of course, apply to acicular spores which are often nearly as long as the ascus in which they are produced. 
There has been a lack of uniformity in the methods of students in measuring asci. Occasionally authors have given the length of what they call the spore bearing portion. In many cases the spores, with the active protoplasm forming them, at first fill the whole of the ascus : when mature, they occupy varying lengths of the upper part depending upon whether they are more or less closely arranged. In Gyromitra esculenta, the mature spores take up only a little over one-third the space; thus, while the ascus itself measures $450-480 \mu$ from the base to the apex, the sporiferous part is $160-170 \mu$. Saccardo says I IO-I $40 \mu$, which is much less than I make it, and I have examined living fructifications of this species for fourteen successive seasons. It is not much more definite to measure what is considered the body of the ascus, and exclude the pedicel; in most cases, it is difficult to tell where the pedicel ends and the ascus body begins. Neither practice appears to me to be as satisfactory as taking the entire length, which has been my custom from the beginning. In clavate or cylindric-clavate asci the width within the walls at the centre of the widest part has been taken as the diameter.

On comparing my measurements with those in Rabh. Krypt. Flo., I find as a rule they run very close, while in many cases they are exactly similar. Occasionally, however, there is a startling difference in the dimensions between us, and that in species which cannot well be confused with others. Take the following. The first column is from Rabh. Krypt. Flo. :-

$$
\begin{array}{lll}
\text { Geopyxis coccinea } & 400-500 \times \mathrm{I} 5-18 \mu . & 370-400 \times \mathrm{I} 5-\mathrm{I} 7 \mu . \\
\text { Geoglossum viscosum } 88-110 \times \mathrm{I} 1 \mu . & 240 \times 12-14 \mu . \\
\text { Otidea aurantia } \quad 250 \times 10-12 \mu . & 190-200 \times \mathrm{II} \mu .
\end{array}
$$

I must leave others interested to settle between the two.

Variable as these structures are in the Discomycetes, they are more so in the Pyrenomycetes. The late Mr. F. Currey in the introduction to his work "On fructifications of Sphæria" (Linn. Soc. Trans. xxii) remarks "The shape of the ascus varies so much, not only in the same species, but in the same specimen, that I do not think it a character to be relied upon"; and I can support this view in many cases. Often, especially in certain pyrenos, a mature ascus will suddenly begin to elongate and stretch to almost twice its former length, while under examination on the glass slip. This is preparatory to casting its spores; after the elongation has taken place, a slight constriction appears below the middle marked by a dark line, the ascus then breaks in two in a circumscissile manner and liberates its spores. There is nothing of this nature in the Discomycetes so far as my observations go. In Ascobolus, the asci elongate a little 
when fully mature and carry up the spores above the surface of the disc which then appears studded with the dark, glistening tips of the protuding asci.

The dehiscence of the asci varies a little in the different groups, from the well defined operculum in the genus Ascophanus, to the semi-lid, and mere slit in the apex in other groups. Some shoot their spores very freely through a slit in the apex as in Helotium; others, as in Orbilia cast them very tardily.

It has long been known that the re-action set up in the ascus on the application of iodine varies in the different groups. In some families, the whole of the ascus is affected, in other the apex only, or a point in the centre of the apex. M. Boudier's classification in his recent European Discomycetes is based partly on this phenomena. But these, and a few other interesting points, are outside the purpose of this paper.

In the appended table of measurements, I have omitted those published by Massee in his "Monograph of the Geoglosseae" and other papers, as they are practically the same as mine; in most cases the figures are precisely similar.

The genera and species follow the classification adopted in the Yorkshire Fungus Flora.

Morchella esculenta $300-350 \times 16-26 \mu$. Gyromitra esculenta $450-480 \times 14-16 \mu$. Helvella crispa $290-310 \times 17-19 \mu$.

$"$ lacunosa $245-250 \times 15 \mu$.

$"$ elastica $310-330 \times 17-19 \mu$. macropus $340-370 \times 15-16 \mu$.

Verpa digitaliformis $290-320 \times 19-20 \mu$.

Rhizina inflata 480-520 $12-16 \mu$. Acetabula vulgaris $260-290 \times$ I 5-1 $7 \mu$. Geopyxis coccinea $370-400 \times 12-13 \mu$.

" cupularis 250-260 $\times 12-13 \mu$.

$" \quad$ albida $200-220 \times 9-10 \mu$.

("Nat." I I 000, p. 7).

Peziza reticulata $400-450 \times$ I 2 - I $4 \mu$. sepiatra $320-360 \times 15-16 \mu$.

recedens $300 \times 18 \mu$

("Nat." I904, p. 4).

ampliata var. tectoria $230-270 \times 13-14 \mu$. subrepanda 330-350 $\times 1$ 8-20 $\mu$. Ada $270-290 \times$ I I-I $2 \mu$.

("Nat." 1908, p. 218).

badia $300-340 \times 13-14 \mu$.

lividula $330-350 \times 12-14 \mu$.
Peziza succosa $300-340 \times 17 \mu$.

Oiidea leporina $140-150 \times 10 \mu$.

$"$ cochleata $240-280 \times 10-1$ I $\mu$.

" alutacea $280 \times \mathrm{I} 2 \mu$.

" aurantia $190-220 \times$ I I $\mu$.

" fibrillosa $270 \times 12-13 \mu$.

Curreyella trachycarpa

$200-230 \times 16-18 \mu$.

Barlaea modesta $250-300 \times 23-26 \mu$.

("Nat." I901, p. I87).

" Crouani $310-330 \times 20 \mu$.

" cinnabarina $280 \times 2 \mathrm{I}-22 \mu$.

" asteroidea $320-360 \times 18 \mu$.

" Persoonii 200-210 $\times 13-14 \mu$.

Humaria rubens $260-290 \times 16 \mu$.

$$
\text { ("Nat." 1900, p. 9). }
$$

("Nat." 1899, p. 27).

haemastigma $180-200 \times 20 \mu$. globoso-pulvinata

I 4 O-I $50 \times 16-18 \mu$.

("Nat." 1908, pp. 214-215).

Piggotii 160-1 $70 \times 12-13 \mu$.

convexula $190-220 \times 14-15 \mu$.

carbonigena $150-170 \times 15 \mu$. 
Humaria melaloma $190-220 \times 10-12 \mu$. macrocystis $220-240 \times 12 \mu$.

" Roumegueri var. carnosissima $200-220 \times 13-14 \mu$. granulata I 80-190 $\times 13^{-1} 5 \mu$. subhirsuta $250-280 \times 14 \mu$. deerrata $190-210 \times 12-13 \mu$. ("Nat." I 899, p. 31, f. 5). Phillipsii $27 \mathrm{O}-290 \times \mathrm{I} 5 \mu$. ("Nat." 1906, p. 9). violacea $250-290 \times$ I I $\mu$. " purpurascens 250-270 $\times 9 \mu$. " jungermannia

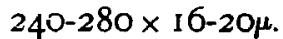

" cervaria I60-1 $80 \times 12-14 \mu$.

" fimeti (=bovina) $260-280 \times 12-14 \mu$. Nicholsonii $65-70 \times 8-9 \mu$. ("Nat." I g01, P. 188, f. 19). Sepultaria semiimmersa

"

\section{sumneriana} $230-270 \times 14-16 \mu$. 290-300 $\times 18-20 \mu$.

Lachnea contorta $300 \times \mathrm{I}^{-1} 5 \mu$.

("Nat." I9O1, p. 182, f. 8). cinnabarina $200-220 \times \mathrm{I} 2 \mu$. crucipila $210-220 \times 17 \mu$. setosa $240-260 \times 18-20 \mu$. ascoboloides $230-240 \times 17-18 \mu$. scutellata $190-210 \times 16 \mu$. umbrorum $260 \times 20 \mu$. theleboloides $220-230 \times 12-14 \mu$. rubra $215-230 \times 15-16 \mu$. timbriata $160-170 \times 12 \mu$.

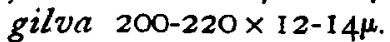
("Nat." 1906, p. 8). cretea $240-250 \times 10 \mu$.

Neotiella polytrichi $(=P$. rutilans $)$ 290-310 $\times 18-20 \mu$.

, nivea $280-300 \times 20 \mu-$ ") leucoloma $200-220 \times 16-17 \mu$. Spharospora trechispora 320-350 $\times 18-22 \mu$. " citrina $300 \times 35 \mu$. ("Nat." I g04, p. 4). Desmazierella acicola $400 \times$ I $1 \mu$. Diplocarpa Curreyana $60 \times 6 \mu$. ("Nat." 1901, p. 183).
Dasyscypha virginea $50-60 \times 5-6{ }^{\circ} \mu$. nivea $45-48 \times 4-5 \mu$. Soppittii $65-75 \times 5-6 \mu$. inquilina $35-40 \times 5 \mu$. crucifera $40-45 \times 5 \mu$. bicolor $50-55 \times 65 \mu$. lactior $50 \times 6.5-7 \mu$. ("Nat." 1904, p. 5). patula $55 \times 55^{\mu}$. conformis $60-65 \times 5 \mu$. leuconica $50 \times 6-6.5 \mu$. ascuna $40-45 \times 8 \mu$. acuum $22-26 \times 5 \mu$. aspidiicola $30-35 \times 5 \mu$. vitreola $60 \times 7-8 \mu$. ("Nat." Igo1, p. 183). hyalina $56-65 \times 7-8 \mu$. fugiens 22-28 $\times 5-6 \mu$. calycina IIO-130 $10-11 \mu$. subtilissima $60-70 \times 5 \mu$. canescens 70-75 $\times 7.5-8 \mu$. palearum 60-63 $\times 5 \mu$. fuscescens 50-55 $\times 5-5^{\circ} 5 \mu$. pygmea 65-70 $\times 5{ }^{\circ} 5-6 \mu$. citricolor $80-90 \times 10-12 \mu$. ("Nat." IgOI, p. 186). spiraeaecola $50-60 \times 5 \mu$. corticalis $70-80 \times 8 \mu$. Carmichaeli $40-44 \times 7 \mu$.

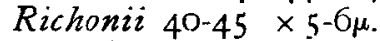
("Nat." IgOI, p. 186). dematicola $80-90 \times 4-5 \mu$. elaphines $32-35 \times 5 \mu$.

Erinella juncicola $60-70 \times 8 \mu$. Nylanderi $80-95 \times 55-6 \mu$.

Echinella setulosa $80 \times 8-10 \mu$. Tapesia fusca $60-70 \times 7-8 \mu$. var. prunicola 80-100 $\times 8 \mu$. casia $30-35 \times 5 \mu$.

Sclerotinia tuberosa $190-200 \times 9-10 \mu$. " sclerotiorum I $50-160 \times 8-9 \mu$.

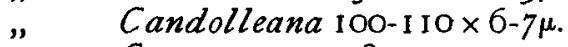
" Curreyana $75-85 \times 55 \mu$.

Ciboria amentacea 90-100 $\times 8 \mu$. C.yathicula coronata $90-110 \times 8-9 \mu$. Helotium badium I10-I $20 \times$ I I-I $4 \mu$. " ferrugineum 90-I IO $\times 9-1 \mathrm{I} \mu$.

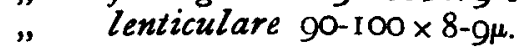


Helotium aureum $80-85 \times 6.6 .5 \mu$. serotinum $120-135 \times 10 \mu$. melleum 135-150 $12 \mu$. Hedwigii $90-100 \times 7 \mu$. lutescens $90-100 \times 8-9 \mu$. uliginosum $75-80 \times 7 \mu$. virgultorum $100-120 \times 8-9 \mu$. aciculare 90-110 $\times 12-14 \mu$. sublenticulare

I 20-1 30 $\times$ 9-10 $\mu$. cyathoideum 50-60 $\times 55^{5}-6 \mu$. scutulum $90-100 \times 8-10 \mu$. herbarum 70-80 $\times 6-8 \mu$. repandum 60-70 $\times 6-7 \mu$. epiphyllum 90-110 $\times$ 9-10 $\mu$. renisporum I 30-140 × 9-I I $\mu$. fagineum 80-90 ×9-10 $\mu$. alniellum 50-60 $\times 6-7 \mu$. gramineum $160-180 \times 12 \mu$. " lacteum 80-100 $\times 14 \mu$.

Gorgoniceps Guernisaci $270-280 \times 6.5-7 \mu$.

Belonium pilosum 78-80 $\times 8 \mu$. Belonidium ventosum $150 \times 7 \mu$. Clarkei $90 \times 8 \mu$.

" Clarkei $90 \times 8 \mu$.

" pruinosum 90-100 $\times 12-13 \mu$. lacustre $80-90 \times 12-13 \mu$.

Mollisia fusca 45-50 $\times 6-7 \mu$. mercurialis $40-50 \times 7 \mu$. effugiens $35-40 \times 5-5^{\circ} 5 \mu$. dilutella $40-44 \times 6-7 \mu$. nervicola $40-50 \times 5 \mu$. ("Nat." Igor, p. I 80). betulicola 50-60 × 9-10 $\mu$. ("Nat." I9OI, p. I 81 ). juncina $40-45 \times 5-6 \mu$. stramineum $40 \times 45 \mu$. fallax 100-120 $\times 9 \mu$. pteridina $35-45 \times 5-6 \mu$.

("Nat." 1899, p. 31, f. I9).

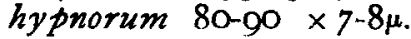

Pseudopeziza rubi $50 \times 6 \mu$.

$R y$ parobius sexdecimsporus

I IO- $125 \times 20-24 \mu$.
Ascophanus argenteus $40-50 \times 20 \mu$. " ochraceus 140-I50 $20 \mu$.

$" \quad$ carneus $230-280 \times 18-28 \mu$. var. cuniculi I 20-190 $\times 20-30 \mu$. equinus I80-220 Crosslandi $170-200 \times 25 \mu$. ("Nat." I 899, p. 29, f. I I). vinosus $100-120 \times 20 \mu$. glaber $110-140 \times 28-30 \mu$. Leveillei $140-160 \times 28-30 \mu$.

("Nat." I 899, p. 29). minutus $140-160 \times 12-13 \mu$. ("Nat." Ig00, p. 8)

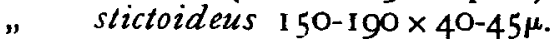

" furfuraceus $180-220 \times 22-28 \mu$.

" immersus $280-360 \times 80-\mathrm{I} 20 \mu$.

Saccobolus granulispermus $100-110 \times 35 \mu$.

("Nat." I 899, p. 30, f. I6).

Orbilia vinosa $50 \times 5 \mu$.

$"$ auricolor $40-45 \times 5-6 \mu$.

"leucostigma $40-45 \times 4-5 \mu$.

Agyrium rufum 75-80 $\times$ IO-I I $\mu$., Coryne sarcoides $140-150 \times 10-12 \mu$. "aquatica $57-60 \times 6 \mu$.

("Nat." I904, p. 6).

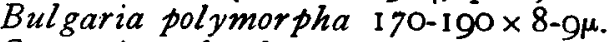

Cenangium furfuraceum I00- $120 \times 6-7 \mu$.

" pulveraceum $55-65 \times 5-6 \mu$.

" dryinum 125-130 $16-17 \mu$.

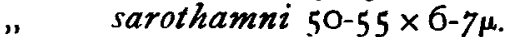
("Nat." I9OI, p. I 79).

Scleroderris rubi $80-85 \times 18-20 \mu$. livida 96-100 × 16-18

Patellea pallida $80 \times 10-12 \mu$.

Karschia lignyota $38-44 \times$ IO-1 $2 \mu$.

Durella melanochlora 60-90 $\times 8-12 \mu$.

("Nat." 1904, p. 6).

Nemacyclus niveus $90-100 \times 10-12 \mu$.

7 rochila craterium $65-70 \times 9 \mu$. 